\title{
Constraints to Senior Management's Capacity to Implement the Performance Management System in Senior Secondary Schools in Botswana
}

\author{
Philip Bulawa ${ }^{1}$ \\ ${ }^{1}$ University of Botswana, Botswana \\ Correspondence: Faculty of Education, P/Bag 706, Gaborone, Botswana. Tel: 267-355-5095. E-mail: \\ bulawap@mopipi.ub.bw
}

Received: February 27, 2013

Accepted: March 25, 2013 Online Published: April 26, 2013

doi:10.5539/ies.v6n5p56

URL: http://dx.doi.org/10.5539/ies.v6n5p56

\begin{abstract}
The performance management system in different forms has been in existence in many countries for some years. In 1999 Botswana like other countries decided to implement a performance management system (PMS) across the entire public service including schools. At its introduction, the government explained the purpose for which this reform was being implemented. Drawing on a grounded theory study about school management's perceptions of the implementation process in senior secondary schools in Botswana, school heads, deputy school heads and heads of houses in twenty-two of the twenty-seven schools were interviewed. The implementation process of the PMS in schools is primarily the responsibility of these management team members. This paper, part of a bigger study conducted to investigate perceptions about the implementation of the performance management system in senior secondary schools in Botswana, explores factors that may have caused senior management to be dissatisfied with their capacity to implement the PMS.
\end{abstract}

Keywords: performance management system, senior management team, resources, time management, regional office

\section{Background}

Many countries have had a wide range of reforms focusing on the performance of schools (Gleeson \& Husbands, 2001). One such reform is the performance management system which has been implemented as a management reform to address and redress concerns, organisations have about performance (Sharif, 2002). Over the years the government of Botswana also introduced some reforms into the entire government including the education sector. One such reform was the performance management system which came into effect in 1999.

The government wanted a performance management system that would ensure effective and efficient public service delivery at a minimal cost thus reducing the burden on taxpayers (Republic of Botswana, 2002). One of the main purposes of this reform was to improve performance in the public service (Republic of Botswana, 2002; Hacker \& Washington, 2004). This is similar in most respects to performance management systems globally. For Brignall and Modell (2000) this is achievable only if the public services adopt management techniques from the private sector. Hughes (2003) reveals that governments, like the private sector, have insisted on the development of performance indicators that would systematically measure the performance of staff over a given period of time than it had ever been done before. However, Anderson's (2008) research shows that there "is minimal support to the expectation that performance management systems improve performance" (p. 552). In other words evidence provided by Anderson (2008) indicates that performance management reforms contribute "small and not (highly) significant improvements of quality...” (p. 554).

In Botswana, whereas the government expressed positive expectation about the PMS, an evaluation of the implementation of the PMS conducted in 2005 by a team of independent consultants from the Institute of Development Management (IDM Consortium) revealed that implementation had some challenges. This evaluation which was carried out amongst a cross section of managers in the different public sector organisations reported limitations about the PMS. One of the weaknesses was in the tools for monitoring, namely the performance agreements (PAs) and the performance development plans (PDPs) which were used for all other public employees. The findings showed that the implementation of both the PDPs and PAs proved a difficult 
task because of the complexity of documentation, and difficulty in matching these documents to the contexts in which managers and their staff were working. Other problems included the problem of reporting frequency, and the paucity of measuring tools. Further revealed in the evaluation report was that the PMS was time consuming, with a lot of time and resources spent at workshops and/or meetings discussing PMS (Republic of Botswana, 2006). Against this background, this study looks at constraints to the implementation of the PMS in the public education sector in Botswana, specifically in senior secondary schools.

\section{Purpose of the Study}

The government of Botswana has invested heavily to have the performance management system implemented in schools. However, the researcher has observed that in spite of such investment, implementation has experienced some major challenges. The purpose of this study is to investigate the senior management teams' role in the implementation of the PMS in senior secondary schools in Botswana. It assesses their perceptions regarding factors that have had some negative impact on their capacity to effectively lead the implementation of the performance management system. This study is therefore guided by the following research questions:

a) What are the senior management teams' perceptions regarding challenges to their role to implement the performance management system (PMS)?

b) What factors led to the senior management teams' dissatisfaction about the PMS?

\section{Literature Review}

Performance management is described in the literature as very important not only in industry in general but also in education in particular since it aims to improve quality of work delivered (Atamturk et al., 2011). Of significance are the conditions for implementing performance management reforms and for managing them. These include the need to ensure that management reforms are supported from the top management, and that there are adequate stakeholder support and technical abilities (Berman \& Wang, 2000). Therefore, in reviewing the literature the study looks at the constraints faced by education systems elsewhere that have attempted to improve service delivery by implementing some performance management systems. As noted by Berman and Wang (2000), performance management reforms require "much groundwork before they could be successfully and fully implemented" (p. 417). This is critical in view of the range of challenges education organisations may encounter which could make it difficult for them to effectively implement performance management systems in their schools. Such challenges include lack of staff confidence about the PMS (Down et al., 2000); inadequate resources to implement the PMS (Desimone, 2002); increasing resistance from staff (Oplatka, 2003); large amount of paperwork involved in the implementation of the PMS (O'Brien \& Down, 2002); and lack of support by government officials (Blackmore, 2004).

The literature on reform suggests that successful implementation of a performance management reform requires the confidence of teachers. This means that the confidence of teachers in the PMS is significant if they are to accept it as a reform worthy to be implemented (Down et al., 2000; O'Brien \& Down, 2002). Evidence of lack of staff confidence about the PMS is reflected in a study by Down et al (2000) that examined the response of a group of Western Australian teachers to the introduction of compulsory performance management in 1997. The study reveals that teachers received this new reform "with significant levels of scepticism, mistrust and anxiety" (p. 213). Teachers indicated that the performance management was not working, which was reflective of their lack of confidence in the reform. In another study by Down et al (1999) which evaluated among other things, the perspectives of a focus group of teachers who by then were being performance managed, concerns also emerged about this reform. Most teachers saw the performance management as a de facto appraisal system that had judged them falsely or inadequately, and as a result they did what their supervisors wanted them to hear just to satisfy them. They lacked trust in the performance management processes as they did not feel there was any effort to build "a spirit of trust, collegiality and respect" (p. 20). The study by Down et al (1999) also shows that teachers perceived the performance management as a reform intended to control and manipulate their work. They regarded it as a reform that made schools "far more competitive, divisive and stressful workplaces" (p. 22).

Another challenge that emerges is that of lack of time and resources required for effective implementation of performance management reforms (Desimone, 2004). There have been reports of concerns by implementers about slow implementation progress due among other things, to inadequate and poor quality of resources. For instance, "teachers were not only sceptical about the educational value of corporate reforms, but the personal-professional consequences of adopting new work practices that were inadequately resourced by government" (O'Brien \& Down, 2002, p. 119). In Pakistan Simkins (2003) also reveals that some of the challenges school heads in public schools face include the low level of resourcing and poor quality provision. The issue of lack of time is also highlighted by Martensson (2000) as one of the major obstacles to 
implementation of reform. Drawing upon Elmore and Mclaughlin (1988) Desimone (2002) also indicates that one of the factors that have frustrated teachers trying to implement school reforms is lack of preparation and planning time.

A reform such as the performance management always brings about change, and as noted by Wallace (2003) change is complex as it is about new experience, new learning and always intruding into people's habitual practices and beliefs within their organisations. McShane and Travaglione (2003) also argue that change can be very stressful and threatening to people's self-esteem and can create an atmosphere of uncertainty about their future. Against this backdrop, it is suggested in the literature read that that effort needs to be taken to avoid possible tensions between those in management and their staff. According to Rhydderch et al (2004), the role of leadership is crucial in encouraging staff as individuals and teams to participate in change to ensure that there is an overlap between individual and organisational goals, since resistance to change is a result of lack of such necessary overlap between individual and organisational goals. McShane and Travaglione (2003) argued that when employees are involved they cease to consider themselves as agents of other people's decisions, but rather feel responsible for organisational success. Their involvement could also minimise the problem of fear of the unknown.

A case study conducted by Ball (1993) that examined school teachers' work in the United Kingdom also alluded to indications of tensions between school management and teachers. Both members of the school management and teachers participated in this study. According to Ball with the implementation of performance reforms, many teachers in the case study were aware of emerging divisions and tensions between them and management. The study reported for instance, a deputy head who indicated that he was worried about the gap that was growing between teachers and management. He stated that the main cause of this gap was that things had changed such that only a small group of people in management were making all the decisions about the school and telling teachers what to do. In other words management was seen as "a mechanism for ensuring the delivery of a national curriculum, and it ties classroom practice, student performance, teacher appraisal, school recruitment and resource allocation into a single bundle of planning and surveillance" (p. 120). The teachers were therefore marginalised even on issues to do with the curriculum, the consequence of which was this growing tension between them and school management.

Another challenge to implementation of performance management reforms is the burden of paperwork involved. According to O'Brien and Down (2002) teachers expressed concern that their work was increasingly consumed by paperwork which involved a diverse range of documentation arising from "management meetings, performance management and other forms of accountability associated with the culture on new managerialism" (p. 123). Similarly, Radin (1998) referred to the burden of paperwork which adversely affected individuals' efforts to implement performance reform initiatives. Radin quotes former United States President Clinton when he was commenting about the implementation of 'The Government Performance Results Act'. The President called for "the need to conquer a mountain of paperwork that is crushing our people and wasting a lot of time and resources" (p. 312).

Finally, are the challenges school managers encounter working with government officials. As pointed out by Simkins et al (2003) the majority of school heads are of the view that they are mainly receivers of policy decisions instead of playing "an active role in school development for quality improvement" (p. 279). However, it would appear that the support school management had expected from the government to drive the reforms they receive from government is lacking. For instance, a study about leadership in schools in Australia by Blackmore (2004) reveals that some principals felt overwhelmed by rapid and extensive reform they were supposed to be implementing in their schools, and that in the process they were being isolated and received minimal support from the government during the implementation process.

\section{Methodology and Methods}

This article is about a qualitative research undertaken in senior secondary schools in Botswana. The popularity of qualitative research arises from the opportunity it provides to researchers to be able to interact with and gather data directly from their research participants to understand a phenomenon from their perspectives (Gay et al., 2009). Not much research has been done to understand school senior managers' experience about the implementation of performance management systems, hence the researcher found the qualitative approach most suitable for an in-depth study of their experience of this phenomenon.

The methodology that guided this qualitative study in investigating the perspectives of senior management teams in senior secondary schools about the implementation of the performance management in their respective schools was grounded theory (Glaser \& Strauss, 1967; Strauss \& Corbin, 1998). I opted for the grounded theory 
methodology because of the procedures it provides researchers to follow in the process of data collection and analysis (LaRossa, 2005). Glaser and Strauss (1967) give some detailed guidelines pertaining to the systematic analysis of the data, complete with clear and specific procedures, and research strategies. Corbin and Strauss (1990) emphasise that grounded theory has specific procedures for data collection and analysis that grounded theory researchers must know to be able to conduct a study. These guidelines are also recognised by Thomas and James (2006) who argue that grounded theory procedures are reflective of an accessible and thoroughly explained approach in qualitative investigation. The description of grounded theory by Mansourian (2006) is that of an enjoyable and exciting procedure which provides directions in research.

In addition to clearly laid down procedures that grounded theory provides for this qualitative study, it is also a methodology that enables researchers to use the data to develop theory rather than to test it (Rennie, 1998). It focuses on inductive strategies of generating theory in comparison to other theoretical perspectives which emphasise theory developed deductively (Patton, 2002). Further explanation by Wiersma and Jurs (2005) is that the theory is grounded in the data, that is, the theory or theories emerge from the data, and therefore there are no preconceived ideas about what the theory will be. Therefore, I found the development of theory inductively attractive and appropriate for my study which investigated participants' lived experience in senior secondary schools in Botswana, a topic that has not been extensively explored.

\section{Population of the Study}

The research participants were members of the senior management team in twenty-two secondary schools out of a total of twenty-seven public senior secondary schools in Botswana. Those interviewed were 22 school heads, 18 deputy school heads and 54 heads of houses. The perceptions of the senior management team about the implementation of the performance management system were central to this study because they work as a team to ensure implementation of reforms in their schools.

\section{Data Collection}

Although the primary source of data used in the study were interview data (Fontana \& Frey, 1994; Rapley, 2004, other sources of data that were used to provide information about the purpose of the PMS in Botswana were government documents. One such important document was "The PMS Philosophy Document" (Republic of Botswana, 2002) which provided extensive information about the implementation of performance management in Botswana's public service.

The interview was selected over other sources of data collection such as questionnaires and observations because as suggested by some grounded theory commentators, it is one of the most essential sources of data (Strauss \& Corbin, 1994). According to Goulding (2002) "with grounded theory the most common form of interview is the face-to-face unstructured or more realistically, semi-structured, open ended, ethnographic, in-depth conversational interview" (p. 59).

Face to face interviews have many advantages for gathering high-quality information for purposes similar to that of this study. One advantage is that interviews enable researchers to clarify questions that may seem confusing to participants as well as gather additional clarification to answers from respondents. With face-to-face interviews researchers can be sure that the people responding are the ones for which the interviews were intended, something that one would not be assured of when using a data collection instrument (Berends, 2006) such as the questionnaire. Cohen et al (2005) argue that one advantage of the interview is its potential for greater depth in comparison to other methods of data collection such as the questionnaire. In addition, it has higher response rate since the participants become more involved and are able to say more about the research.

\section{Data Analysis and Coding}

The process of data analysis involved coding of field work data with notes checked against the recorded interviews and against the codes generated. The first stage of the coding, which comprised numerous iterations and several revisions, was recorded in a Microsoft Excel spreadsheet. The use of the spreadsheet was helpful because it was relatively easy to among other things, modify codes, introduce new coding at different times during the process, and sort the spreadsheet by codes or participants. The coding process began with one transcript at a time, coding phrase by phrase or sentence by sentence (Strauss 1987; Strauss \& Corbin, 1998) depending on the content. 
Table 1. Extract of the open coding spreadsheet

\begin{tabular}{|c|c|c|c|}
\hline Identifier & Code & Text & Comment/memos \\
\hline BBA039 & $\begin{array}{l}\text { Factor needed for } \\
\text { implementation to be } \\
\text { successful: contextualise: } \\
\text { classroom focus }\end{array}$ & $\begin{array}{l}127-128 \text { We expect PMS to make } \\
\text { some focus on the classroom } \\
\text { situation, the educational context. }\end{array}$ & $\begin{array}{l}\text { Teaching and learning } \\
\text { considered core } \\
\text { business of the schools }\end{array}$ \\
\hline BBB099 & $\begin{array}{l}\text { Factor needed for } \\
\text { implementation to be } \\
\text { successful: assessment: } \\
\text { simplify mathematical } \\
\text { calculations }\end{array}$ & $\begin{array}{l}\text { 366-367 The mathematics should be } \\
\text { made less complex. Because some } \\
\text { people are humanities oriented. I am } \\
\text { talking about calculation to a specific } \\
\text { point. }\end{array}$ & $\begin{array}{l}\text { Simplify PMS math } \\
\text { calculations for } \\
\text { paperwork user-friendly }\end{array}$ \\
\hline $\begin{array}{l}\text { MMA068 } \\
\text { a }\end{array}$ & $\begin{array}{l}\text { Factor needed for } \\
\text { implementation to be } \\
\text { successful: contextualise: } \\
\text { focus on core business }\end{array}$ & $\begin{array}{l}252-254 \text { Because of the paper work it } \\
\text { brings, the meetings, people feel } \\
\text { those can still be left out and focus } \\
\text { on our core business which is to } \\
\text { provide quality education. }\end{array}$ & $\begin{array}{l}\text { Perception that PMS } \\
\text { should focus on the } \\
\text { provision of education; } \\
\text { and not paper work and } \\
\text { meetings. }\end{array}$ \\
\hline XXC009 & $\begin{array}{l}\text { Reasons for PMS not } \\
\text { working well: Ministry: } \\
\text { vague appraisal system }\end{array}$ & $\begin{array}{l}49-50 \text { Yeah, as she points out even } \\
\text { with PMS we're still appraised } \\
\text { exactly the same way that we were in } \\
\text { the past but on paper it's supposed to } \\
\text { be different. }\end{array}$ & $\begin{array}{l}\text { Appraisal still as it was } \\
\text { before PMS }\end{array}$ \\
\hline WWC040 & $\begin{array}{l}\text { Factor needed for } \\
\text { implementation to be } \\
\text { successful: PMS: } \\
\text { uniformity }\end{array}$ & $\begin{array}{l}\text { 120-122 So there must be some } \\
\text { coordination, as he has indicated } \\
\text { there should be uniformity in terms } \\
\text { of what the regions are doing, rather } \\
\text { than have different systems for } \\
\text { different regions as it is the case now. }\end{array}$ & $\begin{array}{l}\text { uniformity than have } \\
\text { regions implement } \\
\text { different models }\end{array}$ \\
\hline WWD052 & $\begin{array}{l}\text { Reasons for PMS not } \\
\text { working well: no positive } \\
\text { results }\end{array}$ & $\begin{array}{l}\text { 162-168 But like we were saying } \\
\text { we've not had the model that we can } \\
\text { refer to and say, for this five years or } \\
\text { ten year or whatever, when we look } \\
\text { back this is what PMS has done for } \\
\text { us, despite the few positives that we } \\
\text { talked about. So it may not be } \\
\text { working because there is nothing to } \\
\text { reflect on that we can actually } \\
\text { quantify and say from this point to } \\
\text { this point, this is what PMS has done. }\end{array}$ & $\begin{array}{l}\text { Has not brought any } \\
\text { positive changes }\end{array}$ \\
\hline
\end{tabular}

Table 1 is an illustration of how the coding process was carried out using a Microsoft spreadsheet. The coding of data mainly focused on the interview transcripts complemented by the researcher's field notes taken during the field trip. As the data was analysed, the field notes were checked against the recorded interviews and the codes generated.

Also shown in Table 1 are four columns labelled order, code, text, and comments or memos. The first column was labelled by the researcher "Identifier" to identify the interview data in the third column by participant name and by the position the text held in the interview transcript. The three letters of the code identified the participant while the three digits identified the location of the text in the transcript. The first two letters represent one particular school, with BBA and BBB coming from the same school with the first being the school head and the other the deputy. MMA is a school head in another school. XXC is a head of house in a particular school while WWC and WWD are heads of houses from the same school.

The second column was labelled 'Code' to record how the text in the third column was coded. As indicated in Table 1 the first part or stem is the broader idea in which a family of codes that describe different incidents of 
that stem are nested. For example in the first row, the text 'We expect PMS to make some focus on the classroom situation, the educational context' was coded against Factor needed for implementation to be successful: contextualise: classroom focus. Another example shows that the text "Yeah, as she points out even with PMS we're still appraised exactly the same way that we were in the past but on paper it's supposed to be different" was coded against Reasons for PMS not working well: Ministry: vague appraisal system.

The coding of the data was initially by the smallest unit or micro-unit, such as, 'classroom focus' or 'focus on core business'. With the data coding progressing from one transcript to the next, the 'microcodes' clustered into broader codes which further aggregated into the stems that appear at the beginning of each complete code. Whereas some of the words or phrases used in the codes of the open coding process were those of the researcher, many of them were of the participants or 'in-vivo' codes.

The third column, as already explained, was the column in which the text from the transcripts was 'fragmented' for coding. Almost all the text in each transcript was coded. However, text that was found irrelevant to the topic or had nothing to do with the PMS was uncoded. The creation of the fourth column 'comment/memo' was to record the researcher's reflections of the ideas that emerged from the data (Bulawa, 2011).

In this study, the researcher includes some categories from the data analysis to support the findings. As indicated by Glaser (2002) "concept (category) denotes a pattern that is carefully discovered by constant comparing of theoretically sampled data until conceptual saturation of interchangeable indices" (p. 24). There are instances where numbers are attached to the categories to represent the number of participants whose interview data was allocated to a particular category but only where this is found applicable. The significance of these numbers is that in grounded theory researchers have to account for varied individual participants' experiences of a particular phenomenon. Nevertheless, the extent to which such numbers should be interpreted is limited, hence the numbers should not be understood to represent the precise measures of the prevalence of participants' perceptions. This is so in view of the fact that some participants in the group interviews, did not respond to particular questions or issues under discussion regardless of efforts of the researcher to have them participate.

The findings which are part of a larger study that was undertaken to investigate the senior management team's perceptions about the implementation of the PMS in senior secondary schools, reveal participants' concerns about impediments that make it difficult to fulfil their role of implementing the PMS effectively and sustainably (Bulawa, 2011).

\section{Findings and Discussion}

\subsection{Senior Management Dissatisfied with Their Capacity to Implement the PMS}

The participants reveal that after a period of engagement in the process the senior management team are dissatisfied with the progress that they have made in the implementation of the performance management system in senior secondary schools. Evidence of this are in comments such as the following: "Implementation is really slow" (CCB); "Implementation is not moving" (MMA); "There is no implementation" (BBD); and "Not much implementation is happening" (ZZD). There is concern about paperwork that is not being completed properly. In some schools not all staff have completed their performance development plans, and in others where they have been completed, there have been little or no follow through. Observation and coaching are not being undertaken as fully as they should have been. In some schools, the PMS has even been suspended for periods of time.

Many of the participants express dissatisfaction about their inability to do their job properly. They find this situation frustrating since it does not enable them to perform the most basic functions of their job, which involves, leading the PMS, managing the PMS, and liaising with regional office. The participants' concerns are represented in the Table below (Bulawa, 2011).

Table 2. Categories Representing Participants' Concerns about Implementation

\begin{tabular}{ll}
\hline Title of category & Participants \\
\hline Senior management could not effectively lead the PMS & 50 \\
$\begin{array}{l}\text { Senior management found it difficult to manage the implementation } \\
\text { of the PMS }\end{array}$ & 62 \\
Senior management found it difficult to liaise with regional office & 17 \\
\hline
\end{tabular}

Table from Thesis submitted for the degree of Doctor of Philosophy (Bulawa 2011, p. 173) 


\subsection{Unable to Effectively Lead the PMS}

As suggested in the literature, there is general consensus that management reforms require support from the top (Berman \& Wang, 2000). Therefore, one of the roles of the senior management is that they would lead the implementation process in their respective schools, a role also emphasised by Rhydderch et al (2004). In practice, as the table above indicates, many of the participants reveal that they are not leading the reform to their satisfaction. Their sense of not doing a good job seems to emanate from their own lack of confidence in being able to lead the implementation in their respective schools and also in an increasing loss of confidence in the PMS itself. Two principal codes namely, Senior management lack confidence to lead the PMS (18) and Senior management and their staff are losing confidence in the PMS (14) contribute to the category, Senior management could not effectively lead the PMS.

\subsubsection{Lacking Confidence to Lead the PMS}

The expectation that anybody with the responsibility of leading a reform in an organisation should do so with confidence, does not seem to be the case with many senior managers in senior secondary schools in my study. The literature read shows that successful implementation of a performance management reform requires the confidence of teachers. This means that the confidence of teachers in the PMS is significant if they are to accept it as a reform worthy to be implemented. Like participants in my study, studies carried out amongst teachers in Australia show that implementers lacked the confidence to implement the PMS (Down et al., 2000). As it stands, the major problem that appears to have contributed to the lack of confidence is the inadequate preparation participants in my study feel they have received to lead the PMS. The lack of confidence is seen as compromising what it means to be a leader in two ways. First, is that senior management do not have enough knowledge to be able to lead their teachers to implement the PMS. Second, is the loss of face they experience when they fail to answer questions about the PMS.

The lack of confidence to lead the implementation process is attributed to inadequate information about the PMS TTB explains: "To drive PMS you should be confident but we are not. But because we lack good training and the Ministry is not doing anything to address the problem, as managers we have found it difficult to lead the implementation." Complementing TTD's viewpoint, WWD argues: "You should be confident about what you are talking about. But we can't have the confidence to lead if we are not properly trained. We can't even train our staff to enable them to help us implement this reform." Further discontentment about lack of confidence to lead the PMS was expressed by IIA: "But the training is weak for us to explain to our people with confidence. We can't proceed with the implementation because first of all we need to train our staff on something that we find difficult to do ... we lack capacity."

In addition to senior management experiencing their own lack of confidence, losing the confidence in the people they are leading is also a concern for some. Senior management's ability to provide good explanations and answer staff questions about the PMS is seen as essential for effective leadership. DDC, for example, argues that it is imperative that, as management, they should have the necessary skills and knowledge instead of just being given instructions to implement a reform they do not understand. She points out: "How can we implement PMS when we lack information about it? I should be in a position to stand my ground and explain the PMS to teachers with a lot of confidence." A school head, IIA, describes the consequences of management not having the necessary expertise: "If you are called maybe for one day training, then you go and lead, and these people ask questions. As you fail to explain with confidence, some lose confidence in you wondering where the driver is taking them to."

\subsubsection{Losing Confidence in the PMS}

There is evidence that some of the senior managers across all levels of management have begun to experience a loss of confidence in the PMS itself. They report that they have staff members who have begun to question its value to the schools. This is similar to Down et al (2000) findings about Western Australian teachers' lack of confidence in a compulsory performance management which manifested itself in high levels of scepticism, mistrust and anxiety. The reasons provided by my research participants for the loss of confidence range from senior managers' own inadequate understanding of the purpose of the PMS and how it should be implemented to a perceived disinterest from the Ministry in successfully implementing the PMS in schools.

According to the participants, the lack of understanding about how the PMS should be implemented schools is shared by the Ministry as well as the schools. A school head, MMA, believes that the slow progress of the implementation process at the school level is likely to be on-going into the foreseeable future since even the Ministry, which is supposed to come to the rescue of schools in terms of training, appears to be lacking in skills and knowledge. He explains: "Implementation is not moving as smoothly as one would have liked it to be. It 
looks like everyone, Ministry officers, ourselves in the schools, don't understand how to implement the PMS." At the grassroots level of the "house" within the school, a head of house, MMD indicates: "We have failed to train our staff to understand the importance of implementing the PMS because we also don't understand." Another head of house in a different school, VVC, states that they have failed as management to provide any convincing explanation to their staff regarding the benefits of the PMS to the school. She argues: "We can't even explain to them the material we are supposed to cascade to staff, so teachers don't really see the reason to implement something that does not seem to benefit them."

Since the implementation process has begun, the level of commitment from Ministry appears for many to have decreased. People are questioning why they should bother implementing the PMS when the Ministry itself does not seem to show commitment to the implementation process. Failure to provide training by the Ministry is seen by participants such as AAE as indicative of a lack of commitment: "We struggle alone with little knowledge. Maybe there is no point wasting time trying to implement when our supervisors don't care ... that is the feeling at least in our schools."

Participants provide other examples of the Ministry's apparent lack of commitment to the implementation of the PMS. These include its inability to provide resources, inadequate preparedness, and lack of monitoring. As far as resources are concerned, AAA explains the impact that the lack of resources, especially of reprographics, is having on staff engagement with the PMS: "Right now members of staff are dragging their feet because the resources are inadequate. They believe by not providing resources, the Ministry is not really showing interest in PMS at school level and they, too, should not bother." Another school head, EEA, also concludes that in the Ministry not providing the resources that would help senior managers to better implement the PMS signified their lack of commitment to the reform: "So I wouldn't say the Ministry is serious about PMS in schools, and people are beginning to say, if these people are not showing interest, why should we in the schools?"

In summary, CCA, a school head, summarises the perceptions of those participants who feel that the Ministry has provided inadequate support. He states: "The Ministry has failed the schools; they have not monitored implementation; they can't provide enough resources; training of managers has been poor. With all these problems, all of us including teachers no longer take this reform seriously."

\subsection{Unable to Effectively Manage the PMS}

The participants realise that once implementation has commenced, they could not effectively fulfil all aspects of this role. Their management role involves leading their staff to implement the PMS, allocating resources for implementation, and managing people. However, they do encounter some challenges in the process. The main challenges which are also common in such developed countries as the United States and the United Kingdom as reflected in the literature read concern the resources available (Simkins et al., 2003), the resistance from some staff (Ball, 1998; Oplatka, 2003) and the amount of paperwork involved (Radin, 1998; O'Brien \& Down, 2002). Examples of codes that reflect the extent to which senior managers have found it difficult to manage the PMS are, Senior management cannot allocate resources because there is little or nothing to allocate (11); Staff resistance makes it difficult for senior management to manage the PMS (28); and Senior management spend most of their time managing paper instead of people (18).

\subsubsection{Inadequate Resources Available to Support Implementation}

Provision of resources is very important for the implementation of the PMS and therefore members of staff look up to senior management to allocate resources that would enable the process to be carried out effectively. However, the participants indicate that resources are grossly inadequate in schools. Senior management have little or nothing to allocate to the implementation process which make it difficult for them to manage the PMS. This explanation by QQB shows the frustration senior management have due to failure to provide resources. He states: "The resources have been a major challenge and without them implementation has been badly affected. Like you need money to buy some material for training purposes but it's not readily available." EEA further expresses her comments regarding the exigency of resources for effective management of the PMS. She maintains: "If I were to implement my own PMS I would really want to have resources in place or else it may never get started."

The central role of resources in the management of the PMS is further emphasised by KKA. He cites photocopiers and computers as resources that are essential for the management of the PMS but which senior management cannot provide:

We have to photocopy enough copies of PMS reading material for our teachers but there is no photocopy for us to run workshops about PMS and other school activities. Trainers have to type PMS material and 
other teachers also have to type their own school work, but there is only one computer for everybody.

These slow down progress of the implementation.

\subsubsection{Increasing Resistance}

Over the period that attempts have been made to implement the PMS, some participants have noted that they have to contend with an increase in resistance from some staff. Elsewhere in such countries as the United Kingdom, studies provide proof of resistance to reform as in the case study conducted by Ball (1993) that showed evidence of tensions between school management and teachers due to implementation of performance reforms. A range of possible reasons for the increasing resistance are offered. For instance, the implementation of the performance management implies encroachment of change into schools, and as McShane and Travaglione (2003) suggests, such change is likely to be stressful and threatening to people since it can create uncertainty about their future, a situation that could result in resistance. Participants in my study blame the inadequate preparation of teachers as a possible cause of teacher resistance. IID argues: "There has been some teacher resistance due to lack of progress in the implementation. Up to now teachers have not been adequately trained to understand and be able to implement PMS and they are now beginning to resist." Further on inadequate training, MMD explains: "We have failed to train our staff to understand the importance of implementing the PMS because we also don't understand, and the result has been resistance. They see PMS as intruding into their core business."

Other participants indicate that the resistance might have been caused by the failure of the PMS to adapt to the business of the school. IIB comments: "I think the resistance should be seen in this context. The PMS was never adjusted to the level of a school. It is more relevant to industry, and not aligned to a school set up, hence the resistance." Reflecting on a similar situation that occurred in his school, YYB maintains: "The obvious one, resistance because teachers do not find it relevant to teaching and learning but to industry. They feel it is not the right reform for them and should therefore not be implemented in schools."

\subsubsection{Managers of Paper not People}

Some participants express concern about the amount of paperwork that the PMS entailed. There is a perception that the time and effort that the paperwork takes does not lead to improved performance of their staff. They feel that they have become managers of paper rather than managers of their people. Their issues concern the volume of paperwork, its complexity and most of all, its usefulness.

Participants from all levels of senior management consider the amount of paperwork to be onerous. One school head describe the PMS as a reform that had "brought in a lot of paperwork which is unnecessary" (MMA). Similarly, a deputy school head, IIB indicates: "The other major problem is the amount of paper work involved in PMS. We are completely overwhelmed. NNC, a head of house also claimed that the PMS involved "too much documentation even in comparison to previous reforms in schools." WWA states that the large amounts of paperwork have "become an extra burden that requires a lot of time to complete" and members of staff have become apprehensive about the PMS due to the amount of time they had to spend "just completing paperwork". From KKD's view, the PMS has "become such an extra burden since senior management and staff are spending more time on paperwork." He finds this "counter-productive to the spirit of the PMS which is that of the improvement of performance." FFD also indicates that senior management were inundated with paperwork since they had to "to spend a lot of time completing different types of forms and looking at piles of teachers' completed forms."

There are participants who point out that the completion of paperwork is a complex exercise which is not easy to understand. For GGB, the challenge for members of staff was "the difficulty to complete the PMS forms given to them". GGA refers to the complexity of paperwork as "mind boggling and too academic for the average employee." TTC describes the paperwork as "difficult to understand and complete as well as tedious" and that they spend much of their time advising teachers on how to complete forms which they, as managers, hardly understand.

There is a perception that the amount of time spent by school managers and teachers working on the PMS documents has a negative effect on school management and on teaching and learning. From EEB's recollection of the PMS, right from the time when it was first introduced, paperwork took away school managers from their role of managing schools. Furthermore, he explains: "The amount of paperwork involved kept teachers away from the classroom." FFC is also concerned about the amount of time school personnel are spending on paperwork and the effect on the core business. She explains: "PMS is more about paperwork and this keeps school management and teachers away from their core business for long hours. So I can't say it is helping schools to improve performance, but it is contributing to poor performance." 


\subsection{Unable to Effectively Liaise with Regional Office}

The research participants reveal that while they have expected the regional office to maintain regular contact with the schools to provide supervision and support, the office rarely ever contact them. They maintain that the limited interaction between the school heads and regional office makes it difficult for all members of the senior management including the deputy heads and heads of houses to implement the PMS. Such feeling of frustration as expressed by my participants due to lack of support government officials also reveals itself in other countries' education systems as also revealed in the literature (Blackmore, 2004; Simkins et al., 2003).

The findings show that while participants have made efforts to liaise with the regional office about the implementation of the PMS, the office has not been reciprocal in terms of providing support to make the role of overseeing the PMS less difficult. FFA for instance, explains that as school heads, they have sent written reports to the regional office but rarely ever get feedback. He further indicates: "We had expected that our regional supervisors would keep regular contact with us, but regrettably in most cases, this does not happen." At the time of the interview, he was concerned that as the term was coming to an end they have not heard from or have not been visited by anyone from the regional office. FFA indicates that the Chief Education Officer has neither phoned him nor paid a visit to check on the progress of the implementation process. Further reflecting on Chief Education Officers, ZZB reveals that while they are responsible for the supervision of the school heads in particular, "they hardly ever visit schools for monitoring purposes and give us advice," and that this makes it difficult for school leaders to effectively implement the reform. A head of house, NNB is also concerned that the Chief has not been coming to their school for a long time. He recalls: "I remember seeing him once but even then he didn't stay long enough to get a clear understanding of how we were struggling to implement PMS." WWA complains about Ministry officials for their tendency to be "visible only when they have to talk about the changes that they want to see brought about but never really make follow ups."

The regional office failure to liaise with schools is construed by participants as a major setback to senior management's efforts to oversee the implementation process. As summed up by DDA, the regional office is not visible to discuss with senior management the PMS and give them support as overseers of the implementation process. He explains: "They don't interact with us in spite of our efforts to send progress reports about the PMS. So without their support we are finding it difficult to effectively implement this reform."

\section{Conclusion}

In summary, many senior managers believe that they have been unable to effectively undertake their role as implementers of the PMS. They point out that they are not able to effectively manage the PMS, citing such adverse factors as inadequate resources, increasing resistance from their staff, and the substantial amount of time and effort they spend on managing paperwork instead of managing people. Furthermore, their failure to effectively liaise with the regional office is seen as an impediment to their efforts to implement the PMS. Many point out that their limited capacity in terms of skills and resources affect their ability to effectively lead the implementation of the reform. For many, a lack of confidence in their capacity to lead the implementation of the PMS and the PMS itself has a negative effect on their enthusiasm. The perceptions of senior management is that when implementation has problems, their own staff, the government and the community, would judge them as having failed to fulfil an obligation only they are supposed to perform.

The practical experience of the senior management teams as leaders of the implementation process, provides useful information to the Ministry of Education in Botswana specifically but also to other countries implementing reforms in education. A major implication for practice is for the Ministry of Education to continuously engage the practitioners at the school level in discussions about the implementation of reforms that directly affect them. The participants' insights suggest that while in principle they embrace the idea of the PMS, there are factors that limit the extent to which implementation would be a success. Therefore, if the Ministry could give attention to constraints that limit their capacity to implement the PMS, its future may be more positive.

\section{Recommendation}

This study has revealed that senior management teams face difficulties in their endeavour to lead the implementation of the performance management system in the schools. It is recommended that the Ministry of Education, Skills and Development should continuously evaluate progress in the implementation process to be able to get feedback about challenges schools encounter and feasible strategies that would make the PMS work better. 


\section{References}

Allan, G. (2003). A critique of using grounded theory as a research method. Electronic Journal of Business Research Methods, 2(1), 37-46.

Anderson, S. C. (2008). The Impact of Public Management Reforms on Student Performance in Danish Schools. Public Administration, 86(2), 541-558. http://dx.doi.org/10.1111/j.1467-9299.2008.00717.x

Atamturk, H., Aksal, F. A., Gazi, Z. A., \& Atamturk, A. N. (2011). Evaluation of Performance Management in State Schools: A Case of North Cyprus. Hacettepe Universitesi Egitim Fakultesi (H. U. Journal of Education), 40, 33-43.

Ball, S. J. (1993). Education policy, power relations and teachers' work. British Journal of Educational Studies, 4l(2), 106-121. http://dx.doi.org/10.1080/00071005.1993.9973954

Berends, M. (2006). Survey methods in educational research. In J. L. Green, G. Camilli, \& P. B. Elmore (Eds.), Handbook of complementary methods in education research (pp. 623-640). Mahwah, NJ: Lawrence Erlbaum Associates Publishers.

Berman, E., \& Wang, X. (2000). Performance Measurement in US Counties: Capacity for Reform. Public Administration Review, 60(5), 409-420. http://dx.doi.org/10.1111/0033-3352.00104

Blackmore, J. (2004). Restructuring Educational Leadership in Changing Contexts: A Local/Global Account of Restructuring in Australia. Journal of Educational Change, 5(3), 267-288. http://dx.doi.org/10.1023/B:JEDU.0000041044.62626.99

Brignall, S., \& Modell, S. (2000). An institutional perspective on performance measurement and management in the 'new public sector'. Management Accounting Research, 11(3), 281-306. http://dx.doi.org/10.1006/mare.2000.0136

Bulawa, P. (2011). Implementation of the Performance Management System in Senior Secondary Schools: The Perspective of the Senior Management Team. PhD thesis. Townsville: James Cook University.

Cohen, L., Manion, L., \& Morrison, K. (2005). Research methods in education. London: RoutledgeFalmer.

Corbin, J., \& Strauss, A. (1990). Grounded Theory Research: Procedures, Canons, and Evaluative Criteria. Qualitative Sociology, 13(1), 1-21. http://dx.doi.org/10.1007/BF00988593

Desimone, L. (2002). How can comprehensive school reform models be successfully implemented? Review of Educational Research, 72(3), 433-479. http://dx.doi.org/10.3102/00346543072003433

Down, B., Chadbourne, R., \& Hogan, C. (2000). How are teachers managing performance management? Asia-Pacific Journal of Teacher Education, 28(3), 213-223. http://dx.doi.0rg/10.1080/713650694

Down, B., Hogan, C., \& Chadbourne, R. (1999). Making sense of performance management: Official rhetoric and teachers' reality. Asia-Pacific Journal of Teacher Education, 27(1), 11-24. http://dx.doi.org/10.1080/1359866990270103

Fontana, A., \& Frey, H. F. (1994). Interviewing: The art of science. In N. K. Denzin, \& Y. S. Lincoln (Eds.), Handbook of qualitative research (pp. 361-376). Thousand Oaks, CA: Sage Publications.

Gay, L. R., Mills, G. E., \& Airasian, P. (2009). Educational research: Competencies for analysis and applications. London: Pearson.

Glaser, B. G. (2002). Constructivist Grounded Theory? Forum Qualitative Sozialforschung / Forum: Qualitative Social Research, 3(3), Art. 12. Retrieved from http://www.qualitative-research.net/fqs/

Gleeson, D., \& Husbands, C. (2003). Modernising schooling through performance management: A critical appraisal. Journal of Education Policy, 18(5), 499-511. http://dx.doi.org/10.1080/0268093032000124866

Goulding, C. (2002). Grounded theory: A practical guide for management, business and market researchers. London: Sage Publications.

Hacker, M., \& Washington, M. (2004). How do we measure the implementation of large-scale change? Measuring Business Excellence, 8(3), 52-59. http://dx.doi.org/10.1108/13683040410555618

Hughes, O. E. (2003). Public management and administration: An introduction (3rd ed.). New York: Palgrave Macmillan.

LaRossa, R. (2005). Grounded theory methods and qualitative family research. Journal of Marriage and Family, 67, 837-857. http://dx.doi.org/10.1111/j.1741-3737.2005.00179.x 
Mansourian, Y. (2006). Adoption of grounded theory in LIS research. New Library World, 107(9/10), 386-402. http://dx.doi.org/10.1108/03074800610702589

Martensson, M. (2000). A critical review of knowledge management as a management tool. Journal of Knowledge Management, 4(3), 204-216. http://dx.doi.org/10.1108/13673270010350002

McShane, S., \& Travaglione, T. (2003). Organisational Behaviour on the Pacific Rim. Roseville: McGraw-Hill.

O'Brien, P., \& Down, B. (2002). What are teachers saying about new managerialism? Journal of Educational Enquiry, 3(1), 111-133.

Oplatka, I. (2003). School change and self-renewal: Some reflections from life stories of women principals. Journal of Educational Change, 4, 25-43. http://dx.doi.org/10.1023081708728

Pansiri, N. O. (2011). Performativity in School Management and Leadership in Botswana. Educational Management Administration \& Leadership, 39(6), 751-766. http://dx.doi.org/10.1177/1741143211416386

Patton, M. Q. (2002). Qualitative research \& evaluation methods. Thousand Oaks, CA: Sage Publications.

Radin, B. A. (1998). The Government Performance and Results Act (GPRA): Hydra-Headed Monster or Flexible Management Tool? Public Administration Reveiw, 58(4), 307-316.

Rapley, T. J. (2004). Interviews. In C. Seale, G. Gobo, J. F. Gubrium, \& D. Silverman (Eds.), Qualitative research practice (pp. 15-33). London: Sage Publications.

Rennie, D. L. (1998). Grounded theory methodology: The pressing need for a coherent logic of justification. Theory \& Psychology, 8(1), 101-119. http://dx.doi.org/10.1177/0959354398081006

Republic of Botswana. (2002). Implementation of the Performance Management System (PMS): The PMS Philosophy Document. Gaborone: Government Printer.

Republic of Botswana. (2006). Evaluation of the Implementation of PMS: The Public Service of Botswana. Gaborone: Government Printer.

Rhydderch, M., Elwyn, G., Marshall, M., \& Grol, R. (2004). Organisational change theory and the use of indicators in general practice. Quality and Safety in Health Care, 13, 213-217. http://dx.doi.org/10.1136/qshc.2003.006536

Sharif, A. M. (2002). Benchmarking performance management systems. Benchmarking: An International Journal, 9(1), 62-85. http://dx.doi.org/10.1108/14635770210418588

Simkins, T., Sisum, C., \& Memon, M. (2003). School Leadership in Pakistan: Exploring the Headteachers' Role. School Effectiveness and School Improvement, 14(3), 275-291. http://dx.doi.org/10.1076/sesi.14.3.275.15841

Strauss, A. L. (1987). Qualitative analysis for social sciences. Cambridge: Cambridge University Press.

Strauss, A., \& Corbin, J. (1990). Basics of qualitative research: Grounded theory procedures and techniques. Thousand Oaks, CA: Sage Publications.

Strauss, A., \& Corbin, J. (1994). Grounded Theory Methodology: An Overview. In N. K. Denzin, \& Y. S. Lincoln (Eds.), Handbook of Qualitative Research (pp. 273-285). Thousand Oaks, CA: Sage Publications.

Strauss, A., \& Corbin, J. (1998). Basics of qualitative research: Techniques and procedures for developing grounded theory. Thousand Oaks, CA: Sage Publications.

Thomas, G., \& James, D. (2006). Reinventing grounded theory: Some questions about theory, ground and

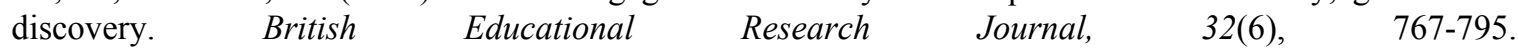
http://dx.doi.org/10.1080/01411920600989412

Wiersma, W., \& Jurs, S. G. (2005). Research Methods in Education: An Introduction. Boston: Pearson Education, Inc. 